\title{
Effect of Snow Pressure on the Distribution of Subalpine Abies mariesii Forests in Northern Honshu Island, Japan
}

\author{
Hiromu Daimaru* and Hiroshi TAODA** \\ $\left(\begin{array}{c}* \text { Kyushu Research Center, Forestry and Forest Products Research Institute, } \\ \text { Kumamoto, 860-0862 Japan } \\ * * \text { Forestry and Forest Products Research Institute, Tsukuba, 305-8687 Japan }\end{array}\right)$
}

\begin{abstract}
The effect of the snow pressure on the distribution of $A$. mariesii forests on northern Honshu Island was examined by GIS-based analysis. A. mariesii forests prevailed in areas, where maximum snow depth is between $100 \mathrm{~cm}$ and $450 \mathrm{~cm}$. In the snowy mountains where maximum snow depth exceeds $350 \mathrm{~cm}$, the $A$. mariesii forest tends to be confined to relatively gentle slopes as snow depth increases. The future snowfall decrease projected by JMA RCM 20 will accelerates the shift of $A$. mariesii forest to higher elevations in the Kitakami Mountains. On the other hand, release from extreme snow pressure on the relatively steep and snowy mountains on the Japan Sea side will not lead to extensive emergence of new A. mariesii forests because most of these mountains are significantly far from existing $A$. mariesii forests.
\end{abstract}

Key words: Abies mariesii, Snow pressure, GIS, Global warming.

\section{Introduction}

The Abies mariesii forest is one of the representative subalpine forests in Japan. It occupies most of the subalpine area of the Oou Montains, which penetrate the central part of northern Honshu Island (Fig. 1). On the other hand, there are many subalpine mountains of northern Honshu Island that lack A. mariesii forests (Shidei, 1952; Fig. 1). These subalpine areas without subalpine coniferous forests have been called "quasi-alpine zones" and are occupied mainly by dwarf scrubs and meadow.

There has been much debate about the development of $A$. mariesii forests and the quasi-alpine zone of northern Honshu Island (e.g. Shidei, 1956; Kaji, 1982; Ono, 1983; Sugita, 1992). Kaji (1982) has attributed the existence of the quasi-alpine zone to the vertical fluctuation of the subalpine forest due to Holocene climate change. Recently, some pollen analytical studies have suggested that the predomi-

Presented at the International Symposium on Food Production and Environmental Conservation in the Face of Global Environmental Deterioration (FPEC) on September 9, 2004.

Received on July 12, 2004.

Accepted on September 10, 2004. nance of $A$. mariesii forest started less than 3000 years ago in many mountains (Morita, 1984, 1985, 1987). In the Hachimantai area (Fig. 1), the expansion started after the 10th century (Morita, 1998).

The factors preventing the expansion of $A$. mariesii forests are still uncertain. A principal factor may be its inability to encroach into heavily snowcovered slopes, because mountains on the Japan Sea side have extreme snowfall in winter. Shidei (1956) has indicated that $A$. mariesii is absent in the mountains on the Japan Sea side, which are among the most snowy subalpine areas in mid-latitudes, and attributed this absence to its lack of stem bending ability, which plays an important role in the survival of several tree species on snowy mountain slopes (Takahashi, 1961). However, the relationship between the $A$. mariesii forests and snow pressure on mountain slopes has not been sufficiently clarified. The future global warming will bring about significant change in snow environment and seriously influence the vegetation on the snowy mountains in Japan.

This study examines the influence of snow pressure on existing $A$. mariesii forests on northern Honshu Island by using GIS and discusses the effect of snowfall change due to global warming on the potential 
distribution of the $A$. mariesii.

\section{Study Method}

To examine the relationship between the distribution of $A$. mariesii forests and snow pressure, raster based GIS (Fig. 2) was applied for northern Honshu Island (Fig. 1). We used GRASS GIS to overlay vegetation, topography and climate data. All data were summarized on a $30^{\prime \prime}$ latitude $\times 45^{\prime \prime}$ longitude (ca. $1 \times 1 \mathrm{~km}$ ) Standard Area Grid (Fig. 2; Anon., 1998). The vegetation layer and climate layers, i.e., air temperature and maximum snowdepth of the winter half year (October-March), were derived from JMA mesh climate data, which were prepared

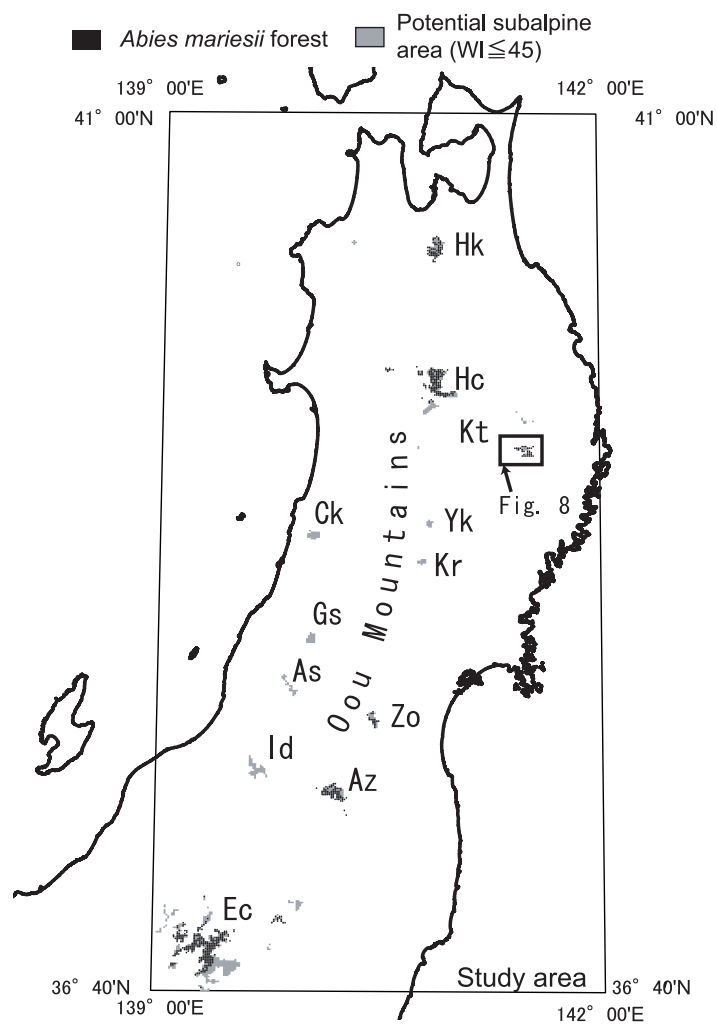

Fig. 1. Map of the study area showing the subalpine zone $(W I \leqq 45)$, the distribution of the Abies mariesii forests, and representative subalpine mountains; Hk : Mt. Hakkoda, Hc : Hachimantai, Kt: Kitakami Mountains, Ck: Mt. Cyokai, Yk: Mt. Yakiishi, Kr: Mt. Kurikoma, Gs: Mt. Gassan, As: Asahi Mountains, Zo: Mt. Zao, Id: Mt. Iide, Az: Mt. Azuma, Ec: Echigo Mountains. in the same projection method as the Standard Area Grid. JMA mesh climate data contain mean values of the past 30 years (1971-2000).

Distribution of $A$. mariesii forests was obtained from the 3rd National Survey on the Natural Environment (NSNE) by the Environment Agency, Japan, in which vegetation maps $(1: 50,000)$ for the entire country were prepared from aerial photographs and ground truthing between 1979 and 1986 (Anon., 1988). The slope map was generated from the DEM with a resolution of $1.5^{\prime \prime}$ latitude $\times 2.25^{\prime \prime}$ longitude $(c a .50 \times 50 \mathrm{~m})$, provided by the Japanese Geographical Survey Institute (JGSI).

Snow pressure on mountain slopes is caused by a deformation of the snowpack. Deformation of the snowpack on a slope consists of snow gliding at its base and snow creep which is slow viscous internal deformation of snow. Evaluating the dynamic force of snow pressure is possible only for limited conditions, such as an artificial slope with constant steepness and roughness. Since the effects of natural vegetation and micro landforms on snow movement is too complex to estimate, we needed to employ a simpler method for evaluating geographical distribution of snow pressure. Since deformation of snowpack is an adjustment process to the pull of gravity, gravitational force applying to a snow body will be a good indicator of snow pressure on a natural slope. In this study, we calculated the downslope component of the gravitational force of the snow in a unit area as "Snow Gliding Force $(S G F)$ ". Figure 3

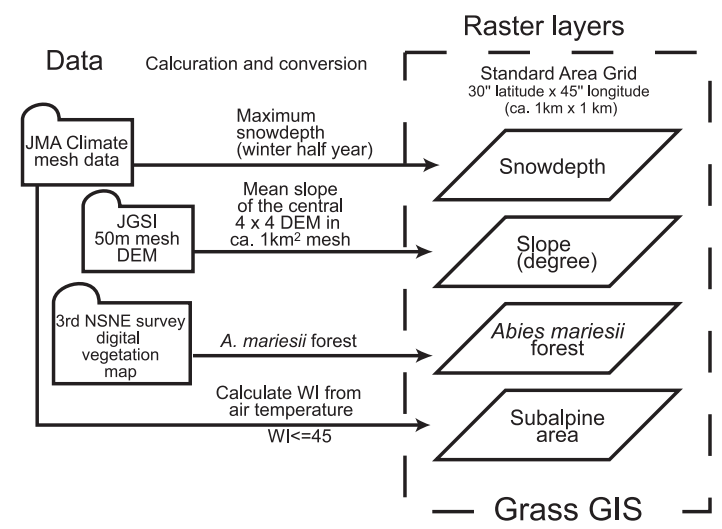

Fig. 2. Flowchart illustrating the integration of digital snowdepth and slope data with the digital vegetation mesh data. 
shows the forces involved when snow is deposited on a slope. The mass of snow with basal area $A$ tends to slide down the slope $\theta$. It is driven by the component $S G F$ of its own weight $W$ resolved parallel to the slope:

$$
\begin{aligned}
& S G F=W \sin \theta \\
& W=D A \rho g .
\end{aligned}
$$

$D, A, \rho, g, \theta$ are snow depth, area of snow base, snow density, acceleration of gravity and slope angle, respectively. For evaluating $S G F$ on a regional scale, the maximum snow depth in the JMA climate data was used as the snow depth $(D)$. Snow density $(\rho)$ was assumed to be 0.5 , which is a representative value for wet granule snow in Japan.

Slope angle $(\theta)$ was calculated for each mesh in the Standard Area Grid. Since each mesh in the vegetation data is assigned to a representative vegetation within $125 \mathrm{~m}$ of its centre (Anon., 1998), 16 DEM points within $125 \mathrm{~m}$ of the centre of each $\mathrm{ca} .1$ $\mathrm{km}^{2}$ grid square were used for calculating. Slope angle calculations were made for the 16 DEM points using $3 \times 3$ neighborhoods (Smith et al., 1997); then the 16 slope angles (in degrees) were averaged and assigned to the slope value $(\theta)$ of the $1 \times 1 \mathrm{~km}$ mesh. Since the original DEM provided by the Japanese Geographical Survey Institute (JGSI) are given in a latitude-longitude co-ordinate system (1.5" latitude $\times 2.25^{\prime \prime}$ longitude), the cell resolution in the metric system is not uniform but depends on latitude and used ellipsoid. In the slope evaluation using JGSI DEM, $x_{\mathrm{s}}$ (cell resolution in the east-west direction)

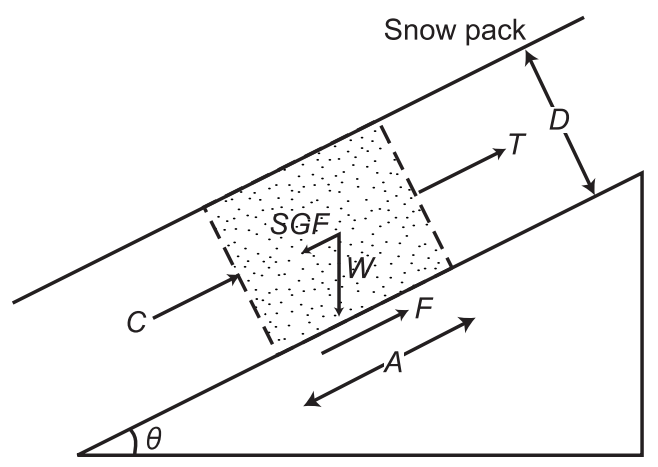

Fig. 3. Snow gliding force of snowpack on a slope. $S G F$ : Force of snow gliding, $W$ : Weight of the snow mass, $\theta$ : Slope angle, $D:$ Snowdepth, $A$ : Basal area, $F$ : Resistance force at ground, $T$ : Tensile force, $C$ : Compressive force. and $y_{\mathrm{s}}$ (cell resolution in the north-south direction) at a particular latitude $(\phi)$ were determined by using the following equation and the Bessel ellipsoid (National Astronomical Observatory, 2001):

$$
\begin{aligned}
& x_{\mathrm{s}}=2.25 \times L_{1} \\
& y_{\mathrm{s}}=1.5 \times L_{2} \\
& L_{1}=\pi a \cos \phi /\left[\left(1-e^{2} \sin ^{2} \phi\right)^{1 / 2} \cdot 180 \cdot 3600\right] \\
& L_{2}=\pi a\left(1-e^{2}\right) /\left[648000 \cdot\left(1-e^{2} \sin ^{2} \phi\right)^{2 / 3}\right]
\end{aligned}
$$

where $a$ is the radius of the earth $(6377397.155 \mathrm{~m})$, $e\left(3.34277317994 \times 10^{-3}\right)$ is the eccentricity, $L_{1}$ and $L_{2}$ are length of $1 \mathrm{~s}$ arcs in the north-south and eastwest directions from each other.

The maximum winter snow depth was used to evaluate the winter snow environment. Monthly mean air temperature was used for "Kira's Warmth Index" $(W I)$, the annual sum of all positive differences between monthly means and $+5^{\circ} \mathrm{C}$ (Kira, 1948, 1977). All digital data were converted into GIS layers in GRASS GIS (GRASS GIS 5.0 pre).

\section{Results and Discussion}

\subsection{Snow and slope environments and the distribu- tion of Abies mariesii forests on northern Honshu Island}

Figure 4 shows the distributions of maximum snowdepth, slope angle and SGF. As noted above, slope angles were calculated for the central part of each $1 \times 1 \mathrm{~km}$ grid. As Shidei (1956) indicated, there is no significant occupation of A. mariesii forest in the Japan Sea side mountains (Fig. 1). Shidei (1956) attributed the lack of $A$. mariesii forests on this side of the mountains to the extreme snow pressure as is shown in Fig. 4c.

Table 1 shows the mesh numbers and percentage cover of $A$. mariesii forest in the subalpine area. The distribution of the $A$. mariesii forests becomes sparser as snowdepth and slope increase. In Table 1, A. mariesii forests are limited to $6 \%$ on the $31-35^{\circ}$ slopes in areas with $350-400 \mathrm{~cm}$ snowdepth. In contrast, in the less snowy classes with $150-300 \mathrm{~cm}$ snowdepth, occupation of $A$. mariesii forests reached to $c a$. 10 to $30 \%$ in the same slope class. Relationships between the appearance of $A$. mariesii forests and the slope and snowdepth environments in subalpine area $(W I \leqq 45)$ are shown in the biplot (Fig. 5). The density of the $A$. mariesii points becomes sparser as snowdepth and slope angle increase.

To evaluate the effect of snow pressure on the distribution of $A$. mariesii forests more objectively, 

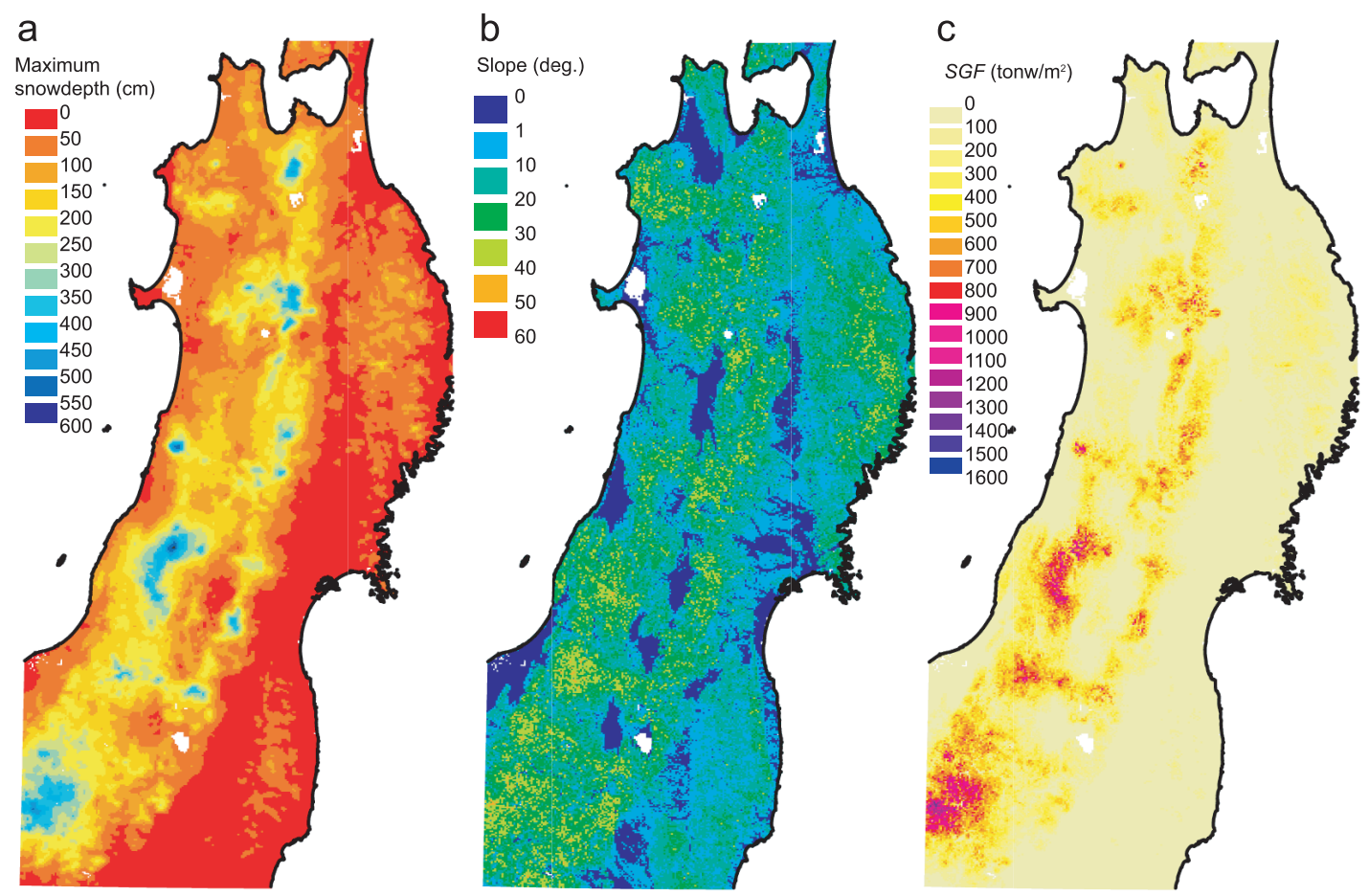

Fig. 4. Maximum snowdepth (a), slope angle at central part of $1 \times 1 \mathrm{~km}$ grid (b) and distribution of $S G F$ calculated from slope and snowdepth (c).

$S G F$ for one square meter's area $\left(A=1 \mathrm{~m}^{2} ;\right.$ Fig. 3$)$ was calculated and superimposed on the biplot (Fig. 5). Though, the $S G F$ contour in Fig. 5 indicates that $A$. mariesii forest rarely occur where the $S G F$ exceeds 1.0 tonw $/ \mathrm{m}^{2}$, the distribution limit of $A$. mariesii forests to $S G F$ is not clear. There will be some reasons for this ambiguity. The first is that $S G F$ does not reflect real snow pressures applying to trees. $S G F$ is simply a geoclimatological indicator representing a potential force to drive snow cover downslope. In most natural slopes, the snow pressure suffers a tree is significantly diminished by the resistance force $F$ at ground, and the tensile and compressive forces $T$ and $C$ (Fig. 3). The second is the accuracy problem of snowdepth data of the JMA mesh climate data, which was made by stepwise multiple regression analysis of snowdepth data in the meteorological stations. Actually in most subalpine mountains, however, snowdepth in a mesh grid (ca. $1 \mathrm{~km} \times 1$ $\mathrm{km}$ ) is not uniform, but significantly variable because of topographical effect and redistribution of snow by strong wind. The third is that the distribution of $A$. mariesii forests has not attained its potential maxi- mum status, which is at equilibrium to present conditions. As mentioned above, the expansion of $A$. mariesii forests during the Holocene time began at around $3000-1000$ years ago.

At the extremely snowy sites where snowdepth exceeds $450 \mathrm{~cm}, A$. mariesii forest is absent even on relatively gentle slopes of less than $20^{\circ}$ (Fig. 5). This probably indicates the limitation of $A$. mariesii occupation caused by snow settlement force due to compaction of snow layer on gentle slopes. Kajimoto et al. (2002) reported that the $A$. mariesii forest on the gentle slope of Mt. Yumori near the Hachimantai area (Fig. 1) was occasionally damaged by settlement force and many trees died in the extremely snowy years. Figure 6 shows situations of representative vegetations appearing in the subalpine area $(W I \leqq 45)$ using the same snow-slope biplot representation as the situation of $A$. mariesii forest. Abies veitchii (Fig. 6a) and Tsuga diversifolia (Fig. 6 b) mostly occupy less snowy sites, where maximum snowdepth does not exceed $250 \mathrm{~cm}$. Tsuga diversifolia is one of the dominant subalpine conifers in the relatively less snowy mountains of Honshu 
Table 1. Pixel numbers and percentage cover of Abies mariesii forests in subalpine area by snowdepth and slope classes.

\begin{tabular}{|c|c|c|c|c|c|c|c|c|c|c|c|}
\hline & \multirow[b]{2}{*}{ Snow depth $(\mathrm{cm})$} & \multicolumn{9}{|c|}{ Slope class (deg.) } & \multirow[b]{2}{*}{ Total } \\
\hline & & $0-5$ & $6-10$ & $11-15$ & $16-20$ & $21-25$ & $26-30$ & $31-35$ & $36-40$ & $41-45$ & \\
\hline \multirow{12}{*}{$\begin{array}{l}\text { All subalpine } \\
\text { sites }\end{array}$} & $0-50$ & & & & 2 & 3 & 3 & & & & 8 \\
\hline & $51-100$ & 1 & 8 & 6 & 19 & 21 & 20 & 17 & 8 & 2 & 102 \\
\hline & $101-150$ & 1 & 3 & 11 & 12 & 33 & 22 & 24 & 15 & 1 & 122 \\
\hline & $151-200$ & 6 & 6 & 32 & 40 & 51 & 43 & 26 & 10 & & 214 \\
\hline & $201-250$ & 4 & 7 & 16 & 11 & 26 & 17 & 14 & 3 & & 98 \\
\hline & $251-300$ & 1 & 15 & 22 & 31 & 30 & 35 & 31 & 6 & & 171 \\
\hline & $301-350$ & 4 & 30 & 51 & 29 & 34 & 30 & 16 & 4 & & 198 \\
\hline & $351-400$ & 3 & 16 & 34 & 34 & 12 & 14 & 6 & 4 & & 123 \\
\hline & $401-450$ & 2 & 6 & 4 & 4 & 11 & 6 & 3 & 1 & & 37 \\
\hline & $451-500$ & & 1 & 5 & 5 & 8 & & 2 & & & 21 \\
\hline & $501-550$ & & & 1 & 2 & & & & & & 3 \\
\hline & Total & 22 & 92 & 182 & 189 & 229 & 190 & 139 & 51 & 3 & 1097 \\
\hline \multirow{12}{*}{$\begin{array}{l}\text { A. mariesii } \\
\text { sites in } \\
\text { subalpine area }\end{array}$} & $0-50$ & & & & 0 & 0 & 0 & & & & 0 \\
\hline & $51-100$ & 0 & 1 & 0 & 0 & 1 & 0 & 0 & 1 & 0 & 3 \\
\hline & $101-150$ & 1 & 0 & 5 & 4 & 12 & 10 & 7 & 4 & 0 & 43 \\
\hline & $151-200$ & 3 & 6 & 24 & 33 & 35 & 20 & 18 & 8 & & 147 \\
\hline & $201-250$ & 2 & 6 & 12 & 5 & 18 & 6 & 5 & 0 & & 54 \\
\hline & $251-300$ & 1 & 8 & 16 & 19 & 17 & 8 & 2 & 0 & & 71 \\
\hline & $301-350$ & 2 & 15 & 26 & 18 & 13 & 5 & 1 & 0 & & 80 \\
\hline & $351-400$ & 2 & 9 & 21 & 16 & 3 & 1 & 0 & 0 & & 52 \\
\hline & $401-450$ & 1 & 1 & 0 & 0 & 0 & 0 & 0 & 0 & & 2 \\
\hline & $451-500$ & & 0 & 0 & 0 & 0 & & 0 & & & 0 \\
\hline & $501-550$ & & & 0 & 0 & & & & & & 0 \\
\hline & Total & 12 & 46 & 104 & 95 & 99 & 50 & 33 & 13 & 0 & 452 \\
\hline \multirow{11}{*}{$\begin{array}{l}\text { A. mariesii } \\
\text { frequency }(\%)\end{array}$} & $0-50$ & & & & 0 & 0 & 0 & & & & \\
\hline & $51-100$ & 0 & 13 & 0 & 0 & 5 & 0 & 0 & 13 & 0 & \\
\hline & $101-150$ & 100 & 0 & 45 & 33 & 36 & 45 & 29 & 27 & 0 & \\
\hline & $151-200$ & 50 & 100 & 75 & 83 & 69 & 47 & 69 & 80 & & \\
\hline & $201-250$ & 50 & 86 & 75 & 45 & 69 & 35 & 36 & 0 & & \\
\hline & $251-300$ & 100 & 53 & 73 & 61 & 57 & 23 & 6 & 0 & & \\
\hline & $301-350$ & 50 & 50 & 51 & 62 & 38 & 17 & 6 & 0 & & \\
\hline & $351-400$ & 67 & 56 & 62 & 47 & 25 & 7 & 0 & 0 & & \\
\hline & $401-450$ & 50 & 17 & 0 & 0 & 0 & 0 & 0 & 0 & & \\
\hline & $451-500$ & & 0 & 0 & 0 & 0 & & 0 & & & \\
\hline & $501-550$ & & & 0 & 0 & & & & & & \\
\hline
\end{tabular}

Island. Sugita and Tani (2001) indicated that seedling establishment of Tsuga diversifolia is difficult in dwarf bamboo-dominated undergrowth widely seen in snowy mountains. In contrast, no A. mariesii forests were found in areas where snowdepth is less than $100 \mathrm{~cm}$ (Fig. 5). This limit does not seem to depend on the steepness of the slope. Betula ermanii appeared in various environments (Fig. 6c). Fagus crenata (Fig. 6d) is a representative species of the montane (cool temperate) zone in Japan, but is occasionally seen also in lower subalpine zones. Quercus mongolica (Fig. 6e) and Alnus maximowiczii (Fig. 6f) appeared in more snowy and steeper sites. They are regarded as the representative species of the "quasi-alpine zone" characterized by extreme snow pressure environments (Ishizuka, 1978).

\subsection{Effect of snowfall change induced by global warming on the distribution of Abies mariesii} forest

The projected $2.0^{\circ} \mathrm{C}$ warming could shift the ideal mountain vegetation zone to an approximately 300 $\mathrm{m}$-higher elevation. If the summit of a mountain is not sufficiently ( $c a .300 \mathrm{~m}$ ) higher than the present montane-subalpine boundary, the subalpine climate zone will be wiped out, and subalpine vegetation will go extinct or be driven into small refuges such as snow banks. Snowfall changes associated with 
changing climate will further complicate this picture. Snowfall regime in mountain area is significantly sensitive to climate changes (Groisman and Davies,

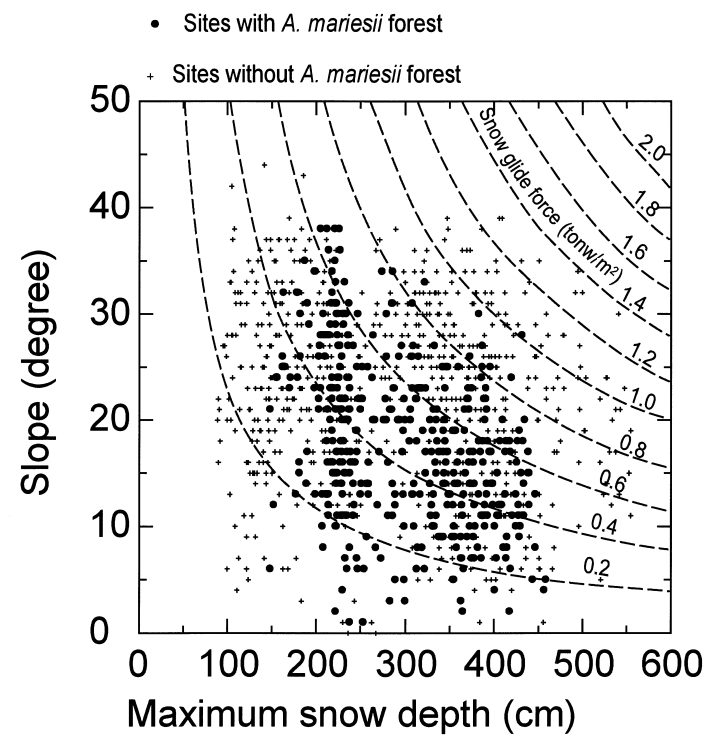

2001). Many studies have indicated that warming in the past was accompanied by snowfall change. For example, the warming in the 'Medieval Warm Period' is believed to have been a relatively modest climate change and did not exceed $1.5^{\circ} \mathrm{C}$ in temperature (Hughes, 1996). However, signs of snowfall variations in this period have been reported in Japanese mountains (Yoshida et al., 1990; Daimaru et al., 2002). The future global warming induced by the enhanced greenhouse effect will be much larger than the warming in the Medieval Warm Period and will bring about significant temporal and spatial variations in the snowfall regime.

For assessing the future trend in regional snow

Fig. 5. Mean slope of the center part of the third mesh, maximum snowdepth, and snow gliding force ( $S G F$ : dashed lines) in the subalpine area $(W I \leqq 45)$ of northern Honshu Island. The closed circles indicate $A$. mariesii forests to be compared with the sites without A. mariesii forest (small crosses).
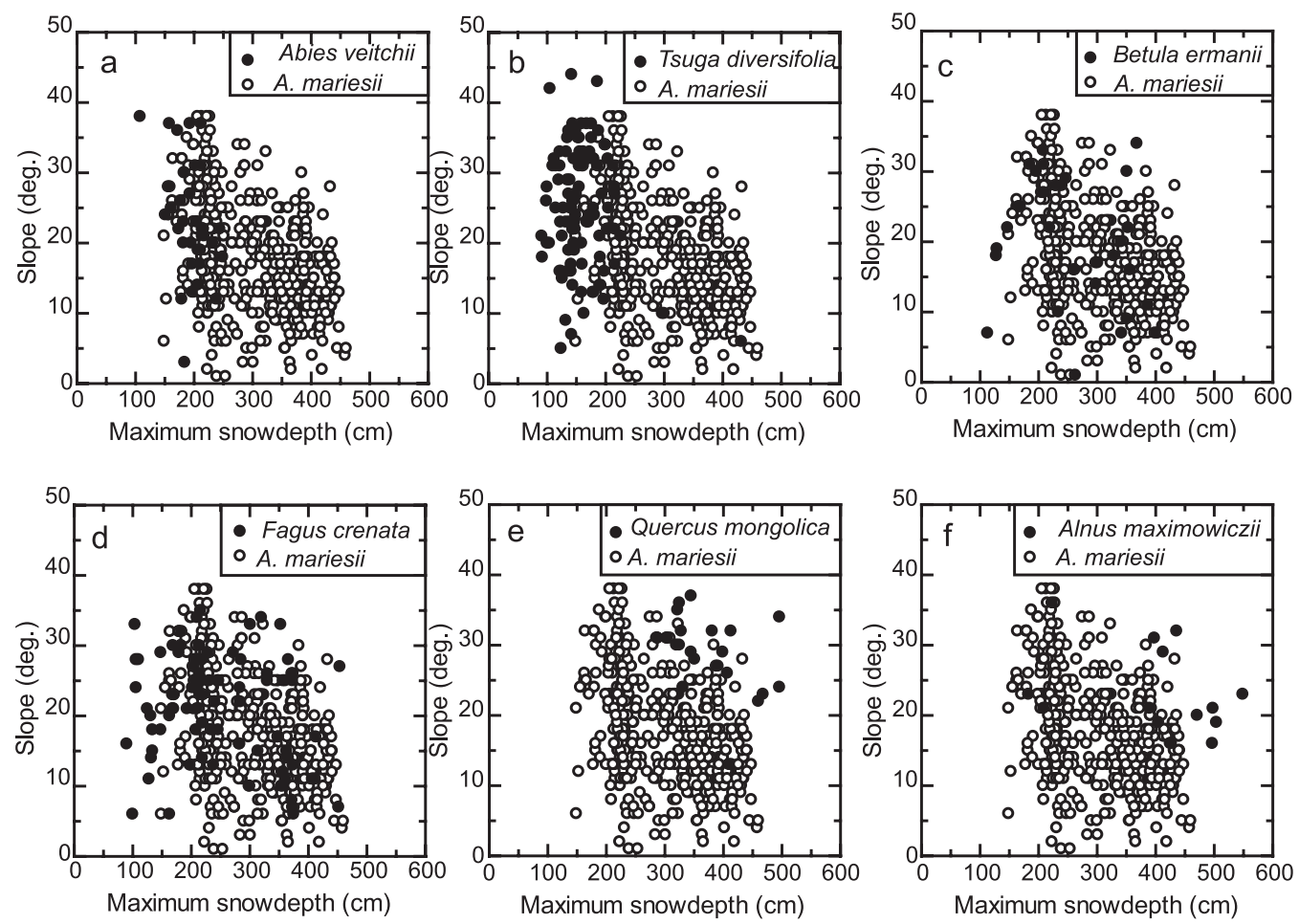

Fig. 6. Snowdepth and slope settings of the representative vegetation in the subalpine area in northern Honshu Island (closed circles) compared with that of $A$. mariesii (open circles). 
regime, current spatial resolution of General Circulation Models (GCM) is generally too crude to adequately represents the orographic detail of mountain regions like the study area. Recently, a regional climate model simulation (JMA RCM20) which has

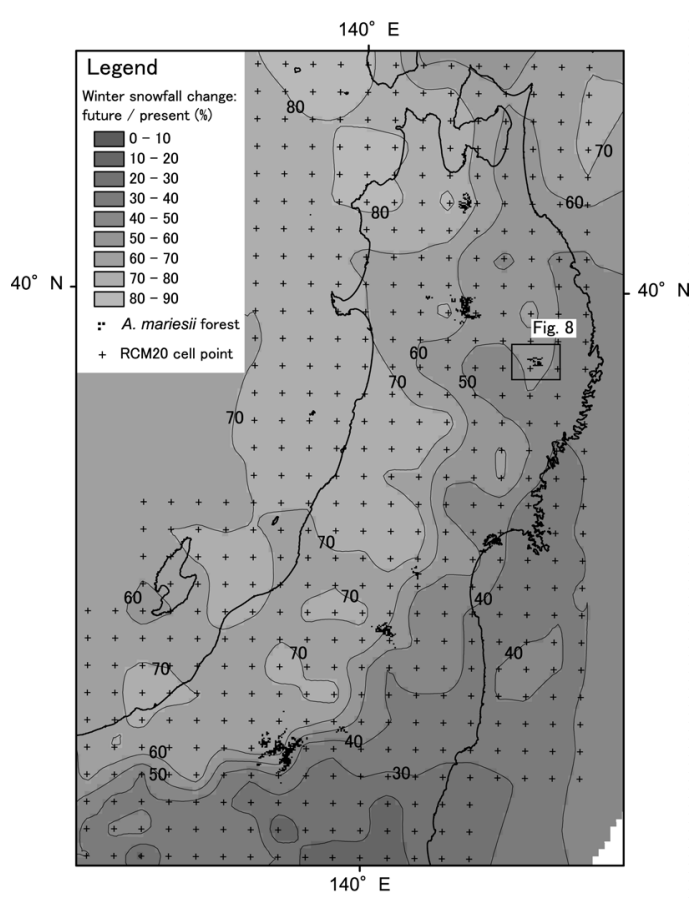

Fig. 7. Annual snowfall changes projected by JMA RCM 20 : Future $(2081-2100) /$ Present (1981-2000). higher resolution ( $c a .20 \mathrm{~km}$ grid) around Japan was applied by the Japan Meteorological Agency. Figure 7 indicates the ratio of annual snowfall in the future (2081-2100) to that of the present (1981-2000) in northern Honshu Island, as calculated by JMA RCM20. This indicates that in the future (20812100), the total annual snowfall in the northern Honshu Island will decrease to about 10 to $80 \%$ of present levels (1981-2000), and that the decrease on the Pacific coast side will be much larger than that on Japan Sea side.

Since present $A$. mariesii forests are restricted to sites where snowdepth exceeds $100 \mathrm{~cm}$ (Fig. 5), the projected snowfall decrease will accelerate the upward shift of the lower limit of $A$. mariesii forest in the relatively less snowy areas. In Fig. 8, $A$. mariesii forests in the Kitakami Mountains are presently situated in a relatively less snowy environment ( $\leqq 200 \mathrm{~cm}$ ) compared with those in other mountains (Fig. 4b). As shown in Fig. 7, the JMA RCM20 projects that snowfall in the Kitakami Mountains will decrease by almost half in the future (20812100). In general, the maximum snowdepth (in water equivalent) is significantly smaller than the total snowfall in the same period. Therefore, the maximum snowdepth in the Kitakami Mountains will decrease to less than $100 \mathrm{~cm}$ in most sites. This will be a critical limit for $A$. mariesii forest occupation. Consequently, the $A$. mariesii forest in the Kitakami Mountains is threatened with extinction by not only temperature change, but also snowfall de-

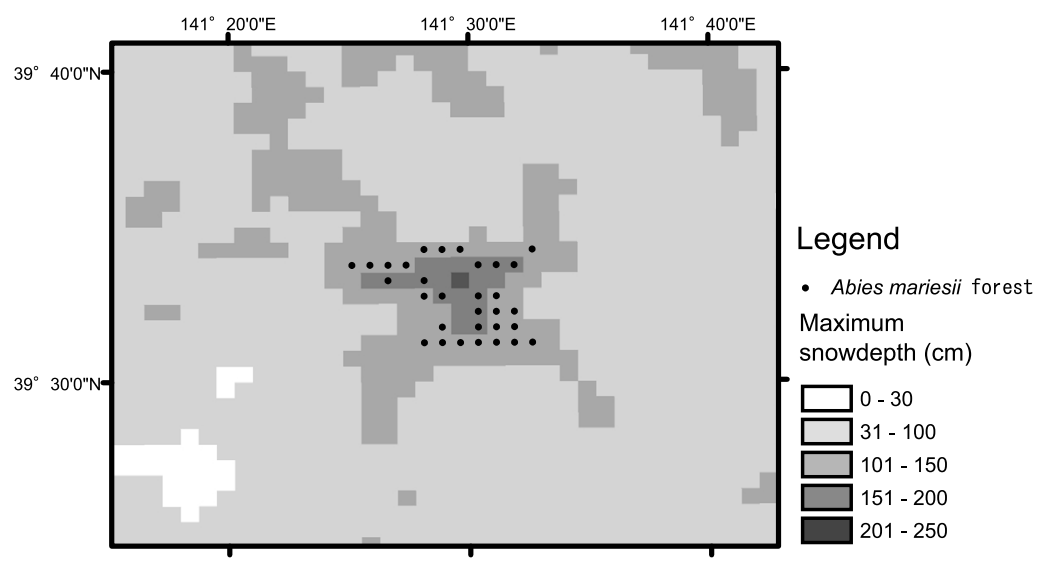

Fig. 8. Distributions of Abies mariesii forests and maximum snowdepth (due to Japan Meteorological Agency, 2002) around Mt. Hayachine in Kitakami Mountains. Locality of the map is indicated in Figs. 1 and 7. 
crease.

In extremely steep and snowy mountains, such as the Asahi Mountains and the Iide Mountains (Fig. 1), the snowfall decrease will bring about a release from severe snow pressure to make some sites tolerable for A. mariesii. This environmental change, however, will not be immediately followed by colonization of new $A$. mariesii forest, because these steep and snowy mountains on the Japan Sea side area have no presence of $A$. mariesii forest except on Mt. Gassan. Since the post-glacial expansions of $A$. mariesii forest depend largely on the existence of core small habitats in each mountain (Sugita, 1992), the emergence of new $A$. mariesii forests due to snow decrease in these Japan-Sea-side mountains will be restricted to areas peripheral to the present $A$. mariesii forests on Mt. Gassan.

\section{Conclusion}

The effect of the snow environment on the distribution of $A$. mariesii forests on northern Honshu Island was examined by GIS-based analysis. $A$. mariesii forests prevails where maximum snowdepth is between $100 \mathrm{~cm}$ and $450 \mathrm{~cm}$. In the snowy mountains where maximum snowdepth exceeds $350 \mathrm{~cm}$, the $A$. mariesii forest tends to be confined to relatively gentle slopes. This supports the Shidei's hypothesis (Shidei, 1956) that snow pressure is the principal factor preventing $A$. mariesii occupation on the steep and snowy mountains on the Japan Sea side. The future snowfall decrease projected by JMA RCM20 will accelerates the shift of $A$. mariesii forest to higher elevations in the Kitakami Mountains. On the other hand, while release from extreme snow pressure on the relatively steep and snowy mountains on the Japan Sea side may expand the potential distribution of $A$. mariesii forest, it will not lead to extensive emergence of new $A$. mariesii forests because most of these mountains are significantly far from presently existing $A$. mariesii forests.

\section{Acknowledgements}

The authors thank Hiroshi Tanaka, Takuya Kajimoto, Hisashi Sugita and Tetsuya Matsui for valuable comments on this study. This study used the Japanese Standard Climate Scenario ver. 1 (2003), provided by the Japan Meteorological Agency. This study was financially supported in part by Ministry of Environment as a research project:
Evaluation of Vulnerability of Natural Ecosystems to Global Warming.

\section{References}

Anon., 1988: Report of the vegetation investigation for the 3rd National Survey on the Natural Environment. Asia Air Survey, Tokyo (in Japanese).

Anon., 1998: Numerical map users guide. 2nd revised version. Japan Map Centre, Tokyo (in Japanese).

Daimaru, H., Ohtani, Y., Ikeda, S., Okamoto, T. and Kajimoto, T., 2002: Paleoclimatic implication of buried peat layers in a subalpine snowpatch grassland on Mt. Zarumori, northern Japan. Catena, 48, 53-65.

Groisman, P.Y. and Davies, T. D., 2001 : Snow cover and the climate system. In Snow ecology (eds. by Jones, H. G., Pomeroy, J. W., Walker, D. A. and Hoham, R.W.). Cambridge University Press, Cambridge, pp. 1-44.

Hughes, M. K., 1996: An overview of global climate over the last 1000 years. In Paleoclimate and environmental variability in Austral-Asian Transect during the past 2000 years. Proceedings of 1995 Nagoya IGBP-PAGES/PEP II Symposium (eds. by Mikami, T., Matsumoto, E., Ohta, S. and Sweda, T.). Nagoya Univ., Nagoya, pp. 98-102.

Ishizuka, K., 1978: Subalpine vegetation of Japan affected by heavy snowfall. Papers on plant ecology to the memory of Dr. Kuniji Yoshioka, pp. 404-428, Sendai (in Japanese).

Kaji, M., 1982: Studies on the ecological geography of subalpine conifers: Distribution pattern of Abies mariesii in relation to the effect of climate in the postglacial warm period. Bull. Tokyo Univ. For., 72, 31-120 (in Japanese with English summary).

Kajimoto, T., Seki, T., Ikesa, S., Daimaru, H., Okamoto, T. and Onodera, H., 2002: Effect of snowfall fluctuation on tree growth and establishment of subalpine Abies mariesii near upper forestlimit of Mt. Yumori, northern Japan. Arctic, Antarctic, and Alpine Research, 34, 191-200.

Kira, T., 1948: Classification of vertical climatic zones based on warmth index (Onryo shisu niyoru suichoku-teki na kiko-tai no wakachikata ni tsuite). Kanchi Nogaku, 2, 143-173 (in Japanese).

Kira, T., 1977: A climatological interpretation of Japanese vegetation zones. In Vegetation science and environmental protection (eds. by Miyawaki, A. and Tuexen, R.). Maruzen, Tokyo, pp. 21-30.

Morita, Y., 1984: The vegetational history of the subalpine zone in Northeast Japan. I. The Azuma Mountains. Jpn. J. Ecol., 34, 347-356 (in Japanese with English summary). 
Morita, Y., 1985: The vegetational history of the subalpine zone in Northeast Japan. II. The Hachimantai Mountains. Jpn. J. Ecol., 35, 411420 (in Japanese with English summary).

Morita, Y., 1987: The vegetational history of the subalpine zone in Northeast Japan. III. The Hakkoda Mountains. Jpn. J. Ecol., 37, 107-117 (in Japanese with English summary).

Morita, Y., 1998: Development of subalpine coniferous forest. In Vegetation history of Japan Islands (eds. by Yasuda, Y. and Miyoshi, N.). Asakurashoten, Tokyo, pp. 179-194 (in Japanese with English summary).

National Astronomical Observatory (ed.), 2001: Chronological scientific tables (Rika nenpyou), Maruzen, Tokyo, 1064 pp.

Ono, Y., 1983: Geomorphology and forestal environment of the subalpine zone in snowy mountains in the Norteastern Japan. J. For. Environ., 25, 1625 (in Japanese with English summary).

Shidei, T., 1952: The forest zone in Northeast Japan. J. Tohoku Branch Jpn. For. Soc., 2, 2-8 (in Japanese).
Shidei, T., 1956: A view on the cause of the lack of coniferouns forests in subalpine area on some mountains in Japan Sea side. J. Jpn. For. Soc., 38, 356-358 (in Japanese).

Smith, C., Brown, N., Pyden, N. and Wormer, D. (eds.), 1997: ERDAS field guide. ERDAS Inc., Atlanta.

Sugita, H., 1992: Ecological geography of the range of the Abies mariesii forest in northern Honshu, Japan, with special reference to physiographic conditions. Ecol. Res., 7, 119-132.

Sugita, T. and Tani, M., 2001: Differences in microhabitat-related regeneration patterns between two subalpine conifers, Tsuga diversifolia and Abies mariesii, on Mount Hayachine, northern Honshu, Japan. Ecol. Res., 16, 423-433.

Takahashi, K., 1961: Plant distribution and snow. J. For. Environ., 2, 19-24 (in Japanese).

Yoshida, M., Yamamoto, K., Higuchi, K., Iida, H., Ohata, T. and Nakamura, T., 1990: First discovery of fossil ice of 1000-1700 year B.P. in Japan. J. Glaciol., 36, 258-259.

\title{
東北日本亜高山帯のオオシラビソ林の分布における雪圧の影響
}

\author{
大丸裕武*・咔田 宏** \\ $\left(\begin{array}{c}* \text { 独立行政法人 森林総合研究所九州支所 } \\ * * \text { 独立行政法人 森林総合研究所 }\end{array}\right)$
}

要 約

雪圧が東北日本亜高山帯のオオシラビソ林の分布に与 える影響について GIS を用いて検討を行った。国土地 理院の $50 \mathrm{~m}$ メッシュ標高データから 3 次メッシュ中心 部の傾斜を求め, 3 次メッシュ植生データ, メッシュ気 候值による寒候期の最大積雪深と重称合わせてオオシラ ビソ林の立地環境を解析した。その結果，（1）オオシラ ビソ林は打抢む称雪深が $100 \sim 450 \mathrm{~cm}$ の領域に出現 すること，（2）積雪深が $350 \mathrm{~cm}$ 以上の地域では，積雪 深の増大とともにオオシラビソ林の分布は緩傾斜な場所 に集中する傾向があること，が明らかになった。このよ
うなオオシラビソ林の分布と傾斜や積雪深との関係は, 四手井（1956）が指摘した雪圧による分布制約を支持し ている。気象庁の地域気候モデル（RCM20）の予測に したがえば, 将来の温暖化にともなう積雪深の減少で北 上山地ではオオシラビソ林の成立が困難になると予想さ れる。一方で, 日本海側の山地では雪圧の緩和によって オオシラビソ林の分布可能域が広がるものの, 月山を除 けば拡大の拠点となる現在の分布を欠いているため，速 やかな分布拡大にはつながりにくいと推察される。 キーワード: オオシラビソ, 雪圧, GIS, 地球温暖化 